\title{
Comparison of Cad and Manual System Efficiency In Pre-Production Preparation Process
}

\author{
Arzu Şen Kılıç* \\ Ege University, Bayındır Vocational School, Sadıkpaşa Mahallesi, Atatürk Cd. No:74, 35840 Bayındır, İzmir, Turkey
}

Corresponding Author: Arzu ŞEN KILIÇ, arzu.senkilic@ege.edu.tr

\begin{abstract}
In the apparel industry, computer aided design (CAD) systems are most commonly used for basic pattern making, grading and marker making processes. Even though there are various software in this area in the market, pattern making process is still performed manually in several apparel businesses. In this research, the amount of time required for the processes of garment technical pattern making, modelling, grading and marker making via CAD systems was compared to time required for the manual method, with the aim of determining the more efficient approach. To this end, time measurements for the steps of these processes, specified by 3 expert pattern designers and 3 CAD operators, were taken and compared. The comparison was focused on the aspects of processes that made a difference in terms of time, the effect of these processes on total time and the identification of the factors that resulted in the time difference. Upper-body garments was chosen as the focus of this study due to the involvement of several steps in the processes of basic pattern making and grading. The acquired data shows that the process times required for CAD systems was shorter than that for manual design in every step that have an important role in the pre-production preparation process.
\end{abstract}

\section{ARTICLE HISTORY}

Received: 28.06 .2018

Accepted: 26.02.2019

\section{KEYWORDS}

Computer aided design, pattern making, modelling, grading, marker making, manual drawing method.

\section{INTRODUCTION}

The concept of garment, which emerged in the past as a result of humankind's instinct to cover themselves up, has come to symbolize life styles, social and cultural levels of people and societies. The meaning attributed by humankind to garment has caused the fashion and apparel sector to become one of the important sectors in world economy. However, in recent years, apparel producers have had to assemble low-cost quality products in a short time in order to be able to compete in the world economy. Today trends tend to rapidly change, and the market time of products is severely diminished. In order to claim a share in such a market where competitors are constantly bringing out new models, it is necessary to launch a great number of products and to shorten the production process.

In the rapidly changing fashion world of today, the quick response to customer demand is the main key to success. Only by embracing technology, can businesses lower costs and increase profits so that they form an example for their competitors (1). All these developments have proven the fact that the use of computer systems in both pre-production preparation and production processes is necessary in the apparel sector, as well as all other fields of industry. Computer Aided Design (CAD) systems were developed in order to perform the various processes involved in the apparel sector via computer, with the aim of lowering the cost of a product and to increase competitive capacity (2). CAD systems are defined as the use of computer utilities in creating, editing and presenting a design (3).

In apparel production, CAD systems are used for garment technical pattern design fabric pattern design and garment model design, production line design, and virtually evaluation of how well garment fits the body. With CAD systems used for the purpose of garment technical pattern design, the processes of basic garment pattern making, modelling, grading and marker making are performed. Those systems enable to create more styles with random

To cite this article: Şen Kılıç A.,2019, "Comparison of Cad and Manual System Efficiency In Pre-Production Preparation Process"

Tekstil ve Konfeksiyon, 29 (1), pp:67-77. 
changes in order to make new designs and the garment patterns as well as the gradings of those designs. Moreover, the integration of CAD systems to the fit evaluation and final adjustments provides mass customization to be realized in the apparel industry (4)

In apparel production, basic specifications of product and production happens in the modeling department. Here, garment patterns of model are made, and a specimen is produced. After the specimen is approved by the customer, patterns are graded according to the size range in the order. Each garment pattern prepared in the modelling department are manually drawn on cardboard and cut. Markers are made by placing these cardboard patterns manually on fabrics and drawing around them, with consideration of the size range in the order (5). Since the fabric is the core of apparel manufacturing, using the fabric efficiently by a welldesigned marker is one of the main goals of those systems. There are many facets of marker planning and reducing fabric consumption is just one of them Fabric is the core of apparel manufacturing. (6). Any decrease in fabric use per unit of garment results in significant increase in profit (7). Thus the minimization in fabric wastage is crucial for the reduction of production costs (8).

A small increase in fabric efficiency provides a large saving in total cost. Fabric cost constitutes about $50-60 \%$ of total raw-material costs in garment production (9). Therefore, marker making is important for both ensuring production quality and lowering cost per unit. All the work done in the modeling department requires a long time and, since it affects and guides production and planning, calls for a busy labor force and qualified personnel. Thus, CAD systems are mainly used for basic garment pattern making, modelling, grading and marker making.

The integration of computers and informations to the production steps of apparel industry started in the mid1970s (10). In time pattern making though these systems became quite advanced, and today, digital platforms play a significant role in this field. Even though there are various software in this area in the market, it is a sad fact that pattern making process is still performed manually in several apparel businesses. Although computerization requires a certain amount of investment, it also provides time saving, accuracy and quality. Apparel companies tend to embrace high technology, however, because of high investments or fear of losing their jobs, businessmen and craftsmen harbor a continued feeling of conflict with regards to CAD systems (11).

Several studies on CAD systems efficiency have been evaluated in the academic platform. In their study, Ondogan and Erdogan compared the use of CAD and manual methods in t-shirt modelling and marker making, identifying the effectiveness of model complexity in this comparison (12). Ozkan conducted a study comparing the efficiency of Assyst, Konsancad and Lectra systems, which are some of the computer aided pattern making systems used in apparel industry (13). Sen and Yucel's study compared CAD and manual methods in skirt modelling in terms of cost per unit (14). In their study, Goksel et al. performed both manual and computer aided trousers pattern modelling and emphasized the efficient use of CAD systems in model application (15). Puri compared the stages of traditional manual method and $C A D$ method by three different garment models were selected based on rising levels of complexity. All patterns were made by experts on both manual and CAD methods and the data was collected by time readings at different specified stages (1). Kayar et al. calculated fabric use ratios by analyzing the markers made for 24 different fabric widths to research the effect of fabric width and product variety on fabric use efficiency (16). Haque's study has made a comparative analysis by making different kinds of markers at constant widths on CAD systems to decrease fabric use (17). In their study, Rahman et al, have created markers for various size ranges and marker widths both manually and via computerized automated marker making systems to compare them in terms of efficiency (7).

In this study, performing technical pattern making, modelling, grading and marker making processes, which are crucial stages of garment production, in the manual method and CAD method were compared in terms of time spent on each stage. It was observed that previous studies in this area focused on total process time, and neglected to include data on sub-stages. In contrast to previous studies in the literature $(1,11,14)$, this study closely examines the substages of each stage and aims to reveal which stage the time difference observed between the two methods stems from.

To this end, three expert pattern designers and three CAD system operators were assigned to establish and perform the process stages involved in pattern design, and time measurements were taken and compared. The facts considered in the comparison included the processes that caused differences between the two methods in terms of time, the effect of these processes on total time, and the identification of factors that brought about the difference. Upper-body garment was chosen as the focus of the study due to the fact that it involves quite a lot of process stages during the basic pattern making and modelling stages.

\section{MATERIALS AND METHODS}

\subsection{Materials}

The focus of this study was chosen as upper-body garment due to the involvement of several steps in the process. For the 4 piece -front, back, sleeve and collar-model button-up shirt, size 40 was produced as main size and sizes 36,38 , 42, 44 were made through grading. Figure 1 shows technical drawing and measurement chart for the model.

In the study, pattern making, grading and marker making processes were performed via Gemini, Gerber Accumark and Optitex CAD system software, which are commercially widely used software that were chosen after review of relevant literature. For the manual preparation of drawings to be used as part of the study, ruler, miter, measuring tape, curve, riga sets, scissors, castor and transparent paper and cardboard were used. Time measurements throughout the study were taken by digital chronometers. 


\begin{tabular}{|c|c|c|c|c|c|c|c|c|c|}
\hline & \multirow{10}{*}{ 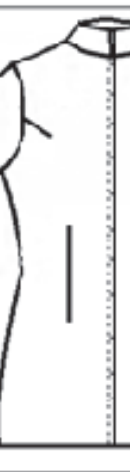 } & \multirow{10}{*}{17} & \multirow{10}{*}{\begin{tabular}{|l|} 
Dimensions Size \\
Chest Circumference \\
Waist Circumference \\
Hip Circumference \\
Front Length \\
Back Length \\
Shoulder width \\
Height \\
Arm Length \\
Wristband \\
\end{tabular}} & 36 & \multirow{10}{*}{\begin{tabular}{|c|}
38 \\
88 \\
70 \\
94 \\
43,5 \\
39,5 \\
13,5 \\
64 \\
29 \\
16 \\
\end{tabular}} & \multirow{10}{*}{\begin{tabular}{|l|}
$\mathbf{4 0}$ \\
92 \\
74 \\
98 \\
44 \\
40 \\
14 \\
65 \\
30 \\
17 \\
\end{tabular}} & \multirow{10}{*}{\begin{tabular}{|c|}
42 \\
96 \\
78 \\
102 \\
44,5 \\
40,5 \\
14,5 \\
66 \\
31 \\
18 \\
\end{tabular}} & \multicolumn{2}{|l|}{44} \\
\hline & & & & 84 & & & & & 100 \\
\hline & & & & 66 & & & & & 82 \\
\hline & & & & 90 & & & & & 106 \\
\hline & & & & 43 & & & & & 45 \\
\hline & & & & 39 & & & & & 41 \\
\hline & & & & 13 & & & & & 15 \\
\hline & & & & 63 & & & & & 67 \\
\hline & & & & 28 & & & & & 32 \\
\hline & & & & & & & & & 19 \\
\hline
\end{tabular}

Figure 1. Upper-body Garment Model and Measurement Chart

\subsection{Methods}

In the study, garment technical pattern making, modelling, grading and marker making processes, which have a significant role in apparel production, were performed via CAD systems and manually, and process time was determined for each method.

While establishing the method for the study, it was aimed to put forward:

- Which method is more efficient in terms of time for each process when pattern-making, modelling, grading and marker making stages are performed manually and on CAD systems,

- Steps that lead to a decrease in time in the more efficient method,

- Steps that cause an increase in time in the less efficient method, and the reasons behind this fact.

Garment patterns can be transferred onto computers in CAD systems in two ways. The first and in literature the most used method $(12,15)$ constitutes of the manual preparation of the basic garment pattern for the main size which is then to be transferred to the computer via digitizer. (18). The second method is to prepare the basic garment pattern for the main size directly using computer tools. In the apparel industry, modelists usually prefer to prepare the garment patterns manually and then convert them into digital form by the help of a digitizer. However, in this study, in order to show the advantage of CAD system tools in pattern making especially for upper-body garment models, which embody several steps of process, in this study, the basic pattern for the main size was prepared via computer tools. In the modelling stage, considering that it is a commonly used model, shoulder dart was moved to the arm hole (Figure 2).

For the marker making, an assortment of 36(1), 38(1), 42(1), $44(1)$ was made. Considering the fact that $150 \mathrm{~cm}$-width fabrics are used for upper-body garment, markers were made for $147 \mathrm{~cm}$-width (Figure 3) (Figure 4).

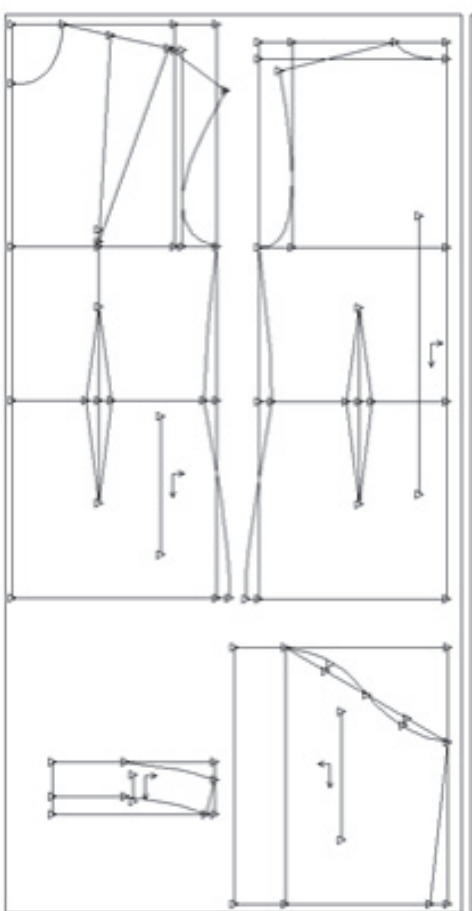

(a) Basic Garment Pattern

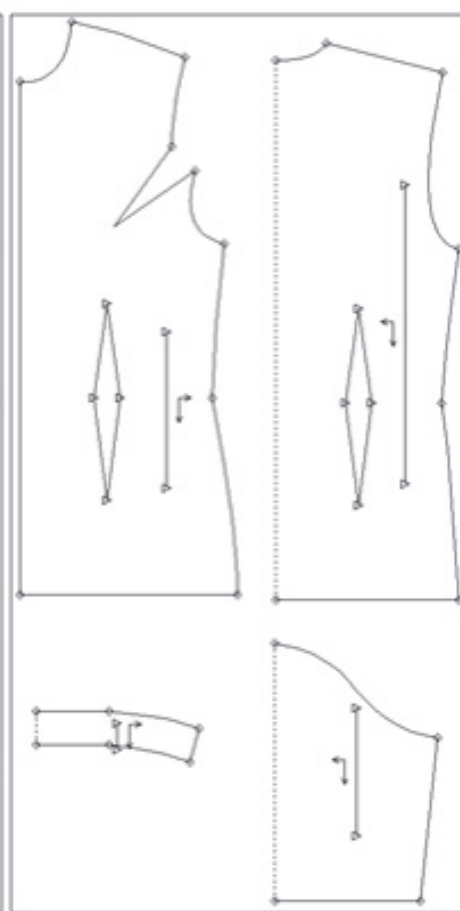

(b) Modelling

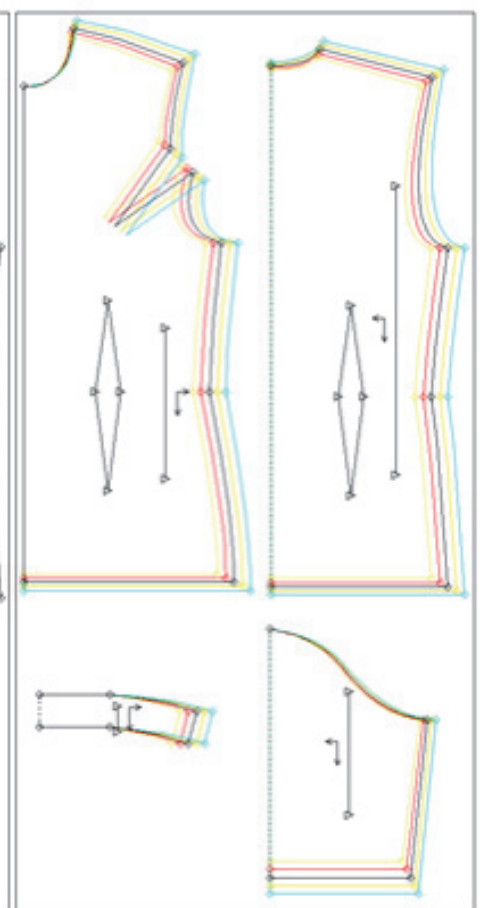

(c) Grading

Figure 2. Images from the CAD System of the Processing Steps 


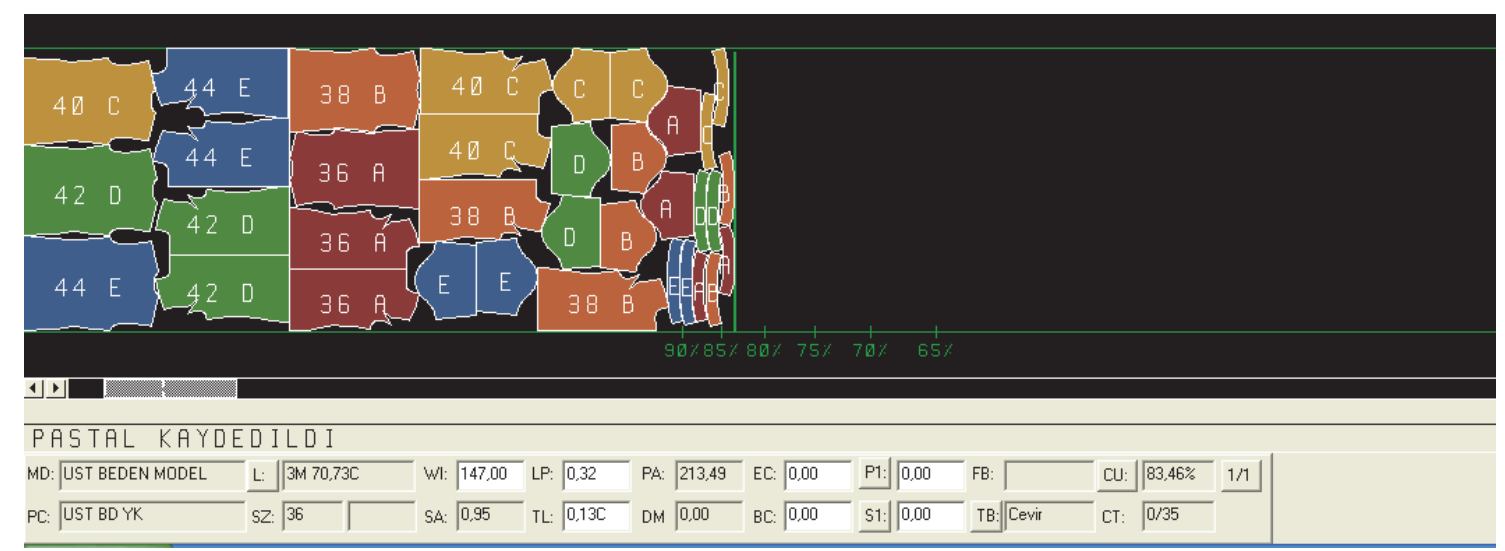

Figure 3. An Example for Markers Made on CAD System

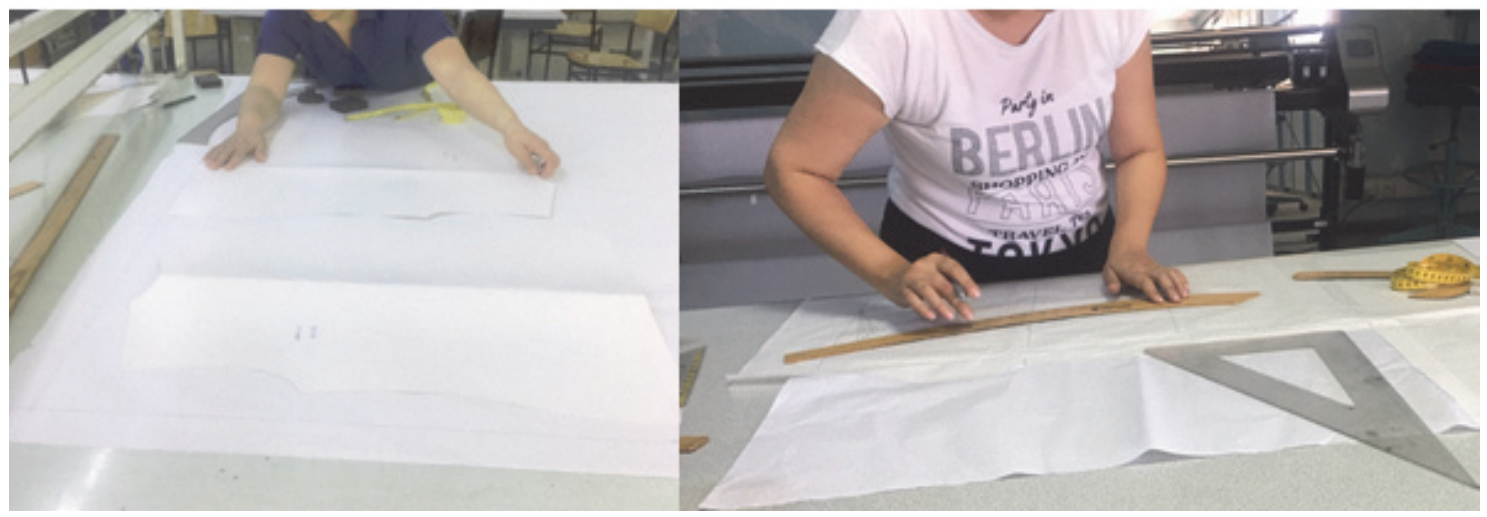

Figure 4. Manual Pattern and Marker Making

As part of the study, to be able to measure times for each basic production process, first, processes and steps involved in both methods were identified (Table 1). After that, 3 experienced garment pattern designers manually performed the specified stages and procedures, and each process stage was timed. Additionally, 3 experienced CAD operators performed the specified stages and procedures using three different CAD systems, and similarly, each process stage was timed.

Table 1. Process Steps in Manual Method and CAD System

\begin{tabular}{|c|c|c|c|}
\hline $\begin{array}{l}\text { Steps } \\
\text { No }\end{array}$ & Process Steps & Sub-operations in Manual Method & Sub-operations in CAD \\
\hline Process I & Basic Pattern Making (PM) & & \\
\hline PM 1 & $\begin{array}{l}\text { Marking measurements in order to } \\
\text { draw the back and drawing auxiliary } \\
\text { lines }\end{array}$ & $\begin{array}{l}\text { - Drawing back midline } \\
\text {-Marking necessary measurements } \\
\text {-Drawing auxiliary lines }\end{array}$ & $\begin{array}{l}\text {-Marking necessary measurements } \\
\text {-Drawing auxiliary lines }\end{array}$ \\
\hline PM 2 & $\begin{array}{l}\text { Drawing back shoulder, back collar, } \\
\text { armhole curves and side seam } \\
\text { shaping }\end{array}$ & $\begin{array}{l}\text { - Drawing shoulder line, } \\
\text {-Drawing back collar and armhole } \\
\text { curves and shaping side seams. }\end{array}$ & $\begin{array}{l}\text { - Drawing shoulder line, } \\
\text {-Drawing back collar, armhole } \\
\text { curves and shaping side seams. }\end{array}$ \\
\hline PM 3 & $\begin{array}{l}\text { Drawing waist dart on the back pattern } \\
\text { piece }\end{array}$ & 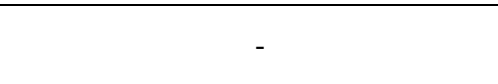 & ( \\
\hline PM 4 & $\begin{array}{l}\text { Marking measurements to draw the } \\
\text { front and drawing auxiliary lines }\end{array}$ & $\begin{array}{l}\text { - Drawing back midline } \\
\text {-Marking necessary measurements } \\
\text {-Drawing auxiliary lines }\end{array}$ & $\begin{array}{l}\text {-Marking necessary measurements } \\
\text {-Drawing auxiliary lines }\end{array}$ \\
\hline PM 5 & $\begin{array}{l}\text { Drawing the shoulder and shoulder } \\
\text { dart on the front pattern piece }\end{array}$ & - & - \\
\hline PM 6 & $\begin{array}{l}\text { Drawing the front collar and armhole } \\
\text { curves and side seam shaping }\end{array}$ & - & - \\
\hline PM 7 & $\begin{array}{l}\text { Drawing waist dart on the front pattern } \\
\text { piece }\end{array}$ & - & - \\
\hline
\end{tabular}


Table 1.

\begin{tabular}{|c|c|c|c|}
\hline $\begin{array}{l}\text { Steps } \\
\text { No }\end{array}$ & Process Steps & Sub-operations in Manual Method & Sub-operations in CAD \\
\hline PM 8 & $\begin{array}{l}\text { Taking measurements on the basic } \\
\text { pattern in order to draw the arm }\end{array}$ & - & - \\
\hline PM 9 & $\begin{array}{l}\text { Marking the measurements to draw the } \\
\text { arm and drawing auxiliary lines }\end{array}$ & $\begin{array}{l}\text { - Drawing arm midline } \\
\text {-Marking necessary measurements } \\
\text {-Drawing auxiliary lines }\end{array}$ & $\begin{array}{l}\text {-Marking necessary measurements } \\
\text {-Drawing auxiliary lines }\end{array}$ \\
\hline PM 10 & Drawing the armhole curve & - & - \\
\hline PM 11 & $\begin{array}{l}\text { Taking measurements on the basic } \\
\text { pattern in order to draw the collar }\end{array}$ & - & - \\
\hline PM 12 & $\begin{array}{l}\text { Marking the measurements to draw the } \\
\text { collar and drawing auxiliary lines }\end{array}$ & $\begin{array}{l}\text { - Drawing neck midline } \\
\text {-Markingnecessary measurements } \\
\text {-Drawing auxiliary lines }\end{array}$ & $\begin{array}{l}\text {-Marking necessary measurements } \\
\text {-Drawing auxiliary lines }\end{array}$ \\
\hline PM 13 & Drawing the neck curve & - & - \\
\hline ProcessII & Modelling (M) & & \\
\hline M 1 & $\begin{array}{l}\text { Transferring back pattern piece, seam } \\
\text { allowance }\end{array}$ & $\begin{array}{l}\text {-Transferring the back-pattern piece } \\
\text { onto cardboard, seam allowance } \\
\text {-Cutting the cardboard pattern }\end{array}$ & $\begin{array}{l}\text { Obtaining the back pattern piece } \\
\text { from the main body pattern }\end{array}$ \\
\hline M 2 & $\begin{array}{l}\text { Moving the shoulder dart to the } \\
\text { armhole in the front pattern piece }\end{array}$ & $\begin{array}{l}\text {-Transferring the front pattern piece } \\
\text { onto transparent paper } \\
\text {-Moving the shoulder dart to the } \\
\text { armhole }\end{array}$ & $\begin{array}{l}\text {-Obtaining the front pattern piece } \\
\text { from the main body pattern } \\
\text {-Moving the shoulder dart to the } \\
\text { armhole }\end{array}$ \\
\hline M 3 & $\begin{array}{l}\text { Transferring the front pattern piece, } \\
\text { seam allowance }\end{array}$ & $\begin{array}{l}\text { - Transferring the back-pattern piece } \\
\text { onto cardboard, seam allowance } \\
\text {-Cutting the cardboard pattern }\end{array}$ & - \\
\hline M 4 & $\begin{array}{l}\text { Transferring arm pattern piece, seam } \\
\text { allowance }\end{array}$ & $\begin{array}{l}\text { - Transferring the arm-pattern piece } \\
\text { onto cardboard, seam allowance } \\
\text {-Cutting the cardboard pattern }\end{array}$ & $\begin{array}{l}\text {-Obtaining the arm pattern piece } \\
\text { from the main body pattern }\end{array}$ \\
\hline M 5 & $\begin{array}{l}\text { Transferring neck pattern piece, seam } \\
\text { allowance }\end{array}$ & $\begin{array}{l}\text { - Transferring the arm-pattern piece } \\
\text { onto cardboard, seam allowance } \\
\text {-Cutting the cardboard pattern }\end{array}$ & $\begin{array}{l}\text {-Obtaining the neck pattern piece } \\
\text { from the main body pattern } \\
\text {-Seam allowance for front, back, } \\
\text { arm and neck pattern pieces } \\
\text { simultaneously }\end{array}$ \\
\hline ProcessIII & Grading (G) & - & - \\
\hline G1 & Preparing the grading chart & - & - \\
\hline G 2 & $\begin{array}{l}\text { Preparing the patterns for grading } \\
\text { process }\end{array}$ & $\begin{array}{l}\text {-Transferring the front, back, arm and } \\
\text { neck pattern pieces onto transparent } \\
\text { paper } \\
\text { - Specifying the grading points }\end{array}$ & $\begin{array}{l}\text {-Creating the grading chart and } \\
\text { transferring onto patterns } \\
\text {-Specifying the grading points }\end{array}$ \\
\hline G 3 & $\begin{array}{l}\text { Transferring the grading chart onto the } \\
\text { computer } \\
\text { Grading the back }\end{array}$ & $\begin{array}{l}\text {-Identifying the amounts of grading on } \\
\text { the corners } \\
\text {-Joining the identified corner points }\end{array}$ & $\begin{array}{l}\text {-Transferring the grading chart of } \\
\text { back onto the computer }\end{array}$ \\
\hline G 4 & Grading the front & $\begin{array}{l}\text {-Identifying the amounts of grading on } \\
\text { the corners } \\
\text {-Joining the identified corner points }\end{array}$ & $\begin{array}{l}\text {-Transferring the grading chart of } \\
\text { front onto the computer }\end{array}$ \\
\hline G 5 & Grading the arm & $\begin{array}{l}\text {-Identifying the amounts of grading on } \\
\text { the corners } \\
\text {-Joining the identified corner points }\end{array}$ & $\begin{array}{l}\text {-Transferring the grading chart of } \\
\text { arm onto the computer }\end{array}$ \\
\hline G 6 & Grading the neck & $\begin{array}{l}\text {-Identifying the amounts of grading on } \\
\text { the corners } \\
\text {-Joining the identified corner points }\end{array}$ & $\begin{array}{l}\text {-Transferring the grading chart of } \\
\text { neck onto the computer }\end{array}$ \\
\hline G 7 & $\begin{array}{l}\text { Transferring the graded back pattern } \\
\text { pieces, seam allowance }\end{array}$ & $\begin{array}{l}\text {-Transferring the back-pattern pieces for } \\
\text { each size onto cardboard, seam } \\
\text { allowance, cutting the pattern }\end{array}$ & - \\
\hline G 8 & $\begin{array}{l}\text { Transferring the graded front pattern } \\
\text { pieces, seam allowance }\end{array}$ & $\begin{array}{l}\text {-Transferring the front pattern pieces for } \\
\text { each size onto cardboard, seam } \\
\text { allowance, cutting the pattern }\end{array}$ & - \\
\hline
\end{tabular}




\begin{tabular}{|c|l|l|l|}
\hline $\begin{array}{c}\text { Steps } \\
\text { No }\end{array}$ & \multicolumn{1}{|c|}{ Process Steps } & \multicolumn{1}{|c|}{ Sub-operations in Manual Method } & Sub-operations in CAD \\
\hline G 9 & $\begin{array}{l}\text { Transferring the graded arm pattern } \\
\text { pieces, seam allowance }\end{array}$ & $\begin{array}{l}\text {-Transferring the arm pattern pieces for } \\
\text { each size onto cardboard, seam } \\
\text { allowance, cutting the pattern }\end{array}$ & \\
\hline G 10 & $\begin{array}{l}\text { Transferring the graded collar pattern } \\
\text { pieces, seam allowance }\end{array}$ & $\begin{array}{l}\text {-Transferring the collar pattern pieces } \\
\text { for each size onto cardboard, seam } \\
\text { allowance, cutting the pattern }\end{array}$ & - \\
\hline ProcessIV & \multicolumn{1}{|c|}{ Marker Making (MM) } & - & - \\
\hline MM 1 & Preparation processes & $\begin{array}{l}\text {-Studying/Examining the patterns that } \\
\text { - Drawing the marker making }\end{array}$ & $\begin{array}{l}\text {-Preparing the model and order } \\
\text { files }\end{array}$ \\
\hline MM 2 & Placing the patterns & $\begin{array}{l}\text { - Pattern grainline control } \\
\text { - Control of the number of pattern parts } \\
\text {-Placing the patterns } \\
\text {-Drawing the marker }\end{array}$ & $\begin{array}{l}\text {-Placing the patterns } \\
\text {-Positioning the patterns on screen } \\
\text {-Drawing the marker }\end{array}$ \\
\hline
\end{tabular}

The manual garment pattern designers and CAD operators that took part in the study possess similar training and expertise as their colleagues in the field. Each operator involved in the study were given a list of instructions on the process stages, and the processes of pattern making, modelling, grading, marker making were performed according to this list.

In this study, the data acquired on process times with the Manual Method and CAD systems has been evaluated using The Mann Whitney $U$ test. The Mann Whitney Test is a method of statistical evaluation which compares the medians of two independent samples, and which is nonparametric. It is used if the two independent groups are the same. This test does not necessitate a normal or nearnormal distribution, but it needs the obtainment of the following hypothesis. These hypotesis; Random sampling,
Independent sampling and Independent observations for each sampling (12).

\section{RESULTS}

The data on timing obtained in this study for the basic pattern making, modelling, grading, marker making processes involved in upper-body garment manually and via CAD systems are shown in Table 2. For both methods, the average of timing data acquired from manual pattern designers and CAD operators was compared, and the differences and ratios between them for each basic process were calculated (Table 3 ).

Table 2. The consumption of time by Manual (M) and CAD (C) System according to processes

\begin{tabular}{|c|c|c|c|c|c|c|c|c|}
\hline \multirow[t]{2}{*}{$\begin{array}{c}\text { Steps } \\
\text { No }\end{array}$} & \multicolumn{8}{|c|}{ Process Time } \\
\hline & M1 & M2 & M3 & M Ave & C1 & C2 & C3 & C Ave \\
\hline \multicolumn{9}{|l|}{ Basic Step (BS) I } \\
\hline PM 1 & 185 & 201 & 173 & 186 & 102 & 155 & 192 & 150 \\
\hline PM 2 & 91 & 73 & 93 & 86 & 77 & 98 & 63 & 79 \\
\hline PM 3 & 65 & 58 & 61 & 61 & 75 & 136 & 67 & 93 \\
\hline PM 4 & 171 & 213 & 176 & 187 & 110 & 137 & 90 & 112 \\
\hline PM 5 & 110 & 115 & 129 & 118 & 110 & 117 & 79 & 102 \\
\hline PM 6 & 115 & 116 & 86 & 106 & 45 & 62 & 70 & 59 \\
\hline PM 7 & 54 & 65 & 62 & 60 & 78 & 87 & 0 & 55 \\
\hline PM 8 & 65 & 64 & 71 & 67 & 98 & 45 & 34 & 59 \\
\hline PM 9 & 131 & 126 & 126 & 128 & 95 & 163 & 77 & 112 \\
\hline PM 10 & 59 & 55 & 50 & 55 & 34 & 48 & 12 & 31 \\
\hline PM 11 & 30 & 38 & 27 & 32 & 26 & 10 & 2 & 13 \\
\hline PM 12 & 56 & 52 & 87 & 65 & 55 & 60 & 42 & 52 \\
\hline PM 13 & 31 & 40 & 61 & 44 & 38 & 19 & 19 & 25 \\
\hline Prosess Time & 1163 & 1216 & 1202 & 1194 & 943 & 1137 & 747 & 942 \\
\hline \multicolumn{9}{|l|}{ BS II } \\
\hline M 1 & 371 & 408 & 291 & 357 & 31 & 5 & 15 & 17 \\
\hline M2 & 551 & 520 & 468 & 513 & 108 & 111 & 29 & 83 \\
\hline M 3 & 564 & 531 & 410 & 502 & 0 & 0 & 0 & 0 \\
\hline M4 & 148 & 290 & 207 & 215 & 27 & 0 & 9 & 12 \\
\hline M5 & 81 & 155 & 145 & 127 & 76 & 152 & 78 & 102 \\
\hline
\end{tabular}


Table 2.

\begin{tabular}{|c|c|c|c|c|c|c|c|c|}
\hline $\begin{array}{l}\text { Steps } \\
\text { No }\end{array}$ & \multicolumn{9}{|c|}{ Process Time } \\
\hline & M1 & M2 & M3 & M Ave & C1 & C2 & C3 & C Ave \\
\hline Prosess Time & $\mathbf{1 7 1 5}$ & $\mathbf{1 9 0 4}$ & $\mathbf{1 5 2 1}$ & $\mathbf{1 7 1 3}$ & $\mathbf{2 4 2}$ & $\mathbf{2 6 8}$ & $\mathbf{1 3 1}$ & $\mathbf{2 1 4}$ \\
\hline BS III & & & & & & & & \\
\hline G 1 & 413 & 413 & 413 & 413 & 413 & 413 & 413 & 413 \\
\hline G 2 & 824 & 795 & 775 & 798 & 121 & 18 & 22 & 54 \\
\hline G 3 & 675 & 696 & 488 & 620 & 82 & 43 & 90 & 72 \\
\hline G 4 & 1349 & 1311 & 942 & 1201 & 181 & 42 & 91 & 105 \\
\hline G 5 & 181 & 190 & 224 & 198 & 49 & 19 & 33 & 34 \\
\hline G 6 & 131 & 158 & 155 & 148 & 41 & 4 & 14 & 20 \\
\hline G 7 & 1576 & 1613 & 1333 & 1507 & 0 & 0 & 0 & 0 \\
\hline G 8 & 2144 & 2285 & 1885 & 2105 & 0 & 0 & 0 & 0 \\
\hline G 9 & 740 & 1066 & 948 & 918 & 0 & 0 & 0 & 0 \\
\hline G 10 & 380 & 644 & 580 & 535 & 0 & 0 & 0 & 0 \\
\hline Prosess Time & $\mathbf{8 4 1 3}$ & $\mathbf{9 1 7 1}$ & $\mathbf{7 7 4 3}$ & $\mathbf{8 4 4 2}$ & $\mathbf{8 8 7}$ & $\mathbf{5 3 9}$ & $\mathbf{6 6 3}$ & $\mathbf{6 9 6}$ \\
\hline BS IV & & & & & & & & \\
\hline MM 1 & 448 & 432 & 492 & 457 & 178 & 101 & 88 & 122 \\
\hline MM 2 & 2293 & 4175 & 3109 & 3192 & 730 & 807 & 546 & 694 \\
\hline Prosess Time & $\mathbf{2 7 4 1}$ & $\mathbf{4 6 0 7}$ & $\mathbf{3 6 0 1}$ & $\mathbf{3 6 5 0}$ & $\mathbf{9 0 8}$ & $\mathbf{9 0 8}$ & $\mathbf{6 3 4}$ & $\mathbf{8 1 7}$ \\
\hline Total Time & $\mathbf{1 4 0 3 2}$ & $\mathbf{1 6 8 9 8}$ & $\mathbf{1 4 0 6 7}$ & $\mathbf{1 4 9 9 9}$ & $\mathbf{2 9 8 0}$ & $\mathbf{2 8 5 2}$ & $\mathbf{2 1 7 5}$ & $\mathbf{2 5 6 9}$ \\
\hline
\end{tabular}

Table 3. Time Saved Between the Manual and CAD Process

\begin{tabular}{|l|c|c|c|c|}
\hline Basic Steps & $\begin{array}{c}\text { Manuel } \\
\text { Average }(\mathbf{s n})\end{array}$ & $\begin{array}{c}\text { CAD Average } \\
\text { (sn) }\end{array}$ & $\begin{array}{c}\text { Manuel - CAD } \\
\text { (sn) }\end{array}$ & Manuel / CAD \\
\hline Basic Pattern Making & 1194 & 942 & 252 & 1,3 \\
\hline Modelling & 1713 & 214 & 1499 & 8 \\
\hline Grading & 8442 & 696 & 7746 & 12 \\
\hline Marker Making & 3650 & 817 & 2833 & 4,4 \\
\hline Total Process Time & 14999 & 2569 & 12430 & 5,8 \\
\hline
\end{tabular}

When process times-both in terms of individual process and process stages-for basic pattern making for upper-body garment with the manual method and on CAD systems are considered, it was determined that process times obtained on CAD systems are shorter. As a result of analyzing each process individually, it was observed that the difference between the two systems especially peaks in terms of time spent on curve drawings at stages 6,10 and 13 (Figure 5) (Table 2). The amount of time required to complete these stages manually is observed to be 1.7 times greater than the time required for doing them on CAD systems. In other words, it can be said that the same process of curve drawing can be completed on CAD systems in just $56 \%$ of the time spent doing it manually.
The comparison in modelling revealed that process times were shorter for CAD systems than the manual method both in terms of total process time and for each stage individually (Figure 5). Thorough analysis of the stages demonstrates that the procedures of transferring pattern pieces onto cardboard and seam allowance tend to elongate process time. For example, it was observed that the time required to perform the the $1^{\text {st }}$ stage-transferring the back-pattern piece onto cardboard with seam allowance-manually takes 21 times longer than completing the same task on CAD systems. In other words, it can be said that the same process of curve drawing can be completed on CAD systems in about $5 \%$ of the time spent doing it manually.

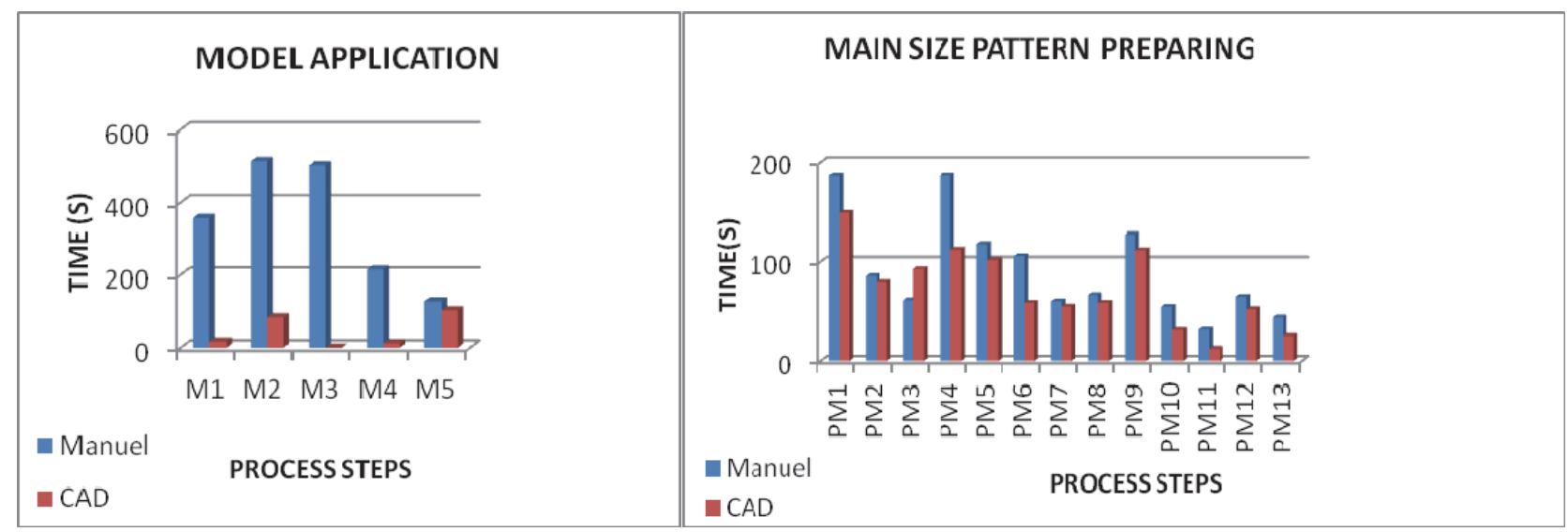

Figure 5. Comparison of Manual and CAD Systems in Terms of Process Time of Basic Pattern Making and Modelling 


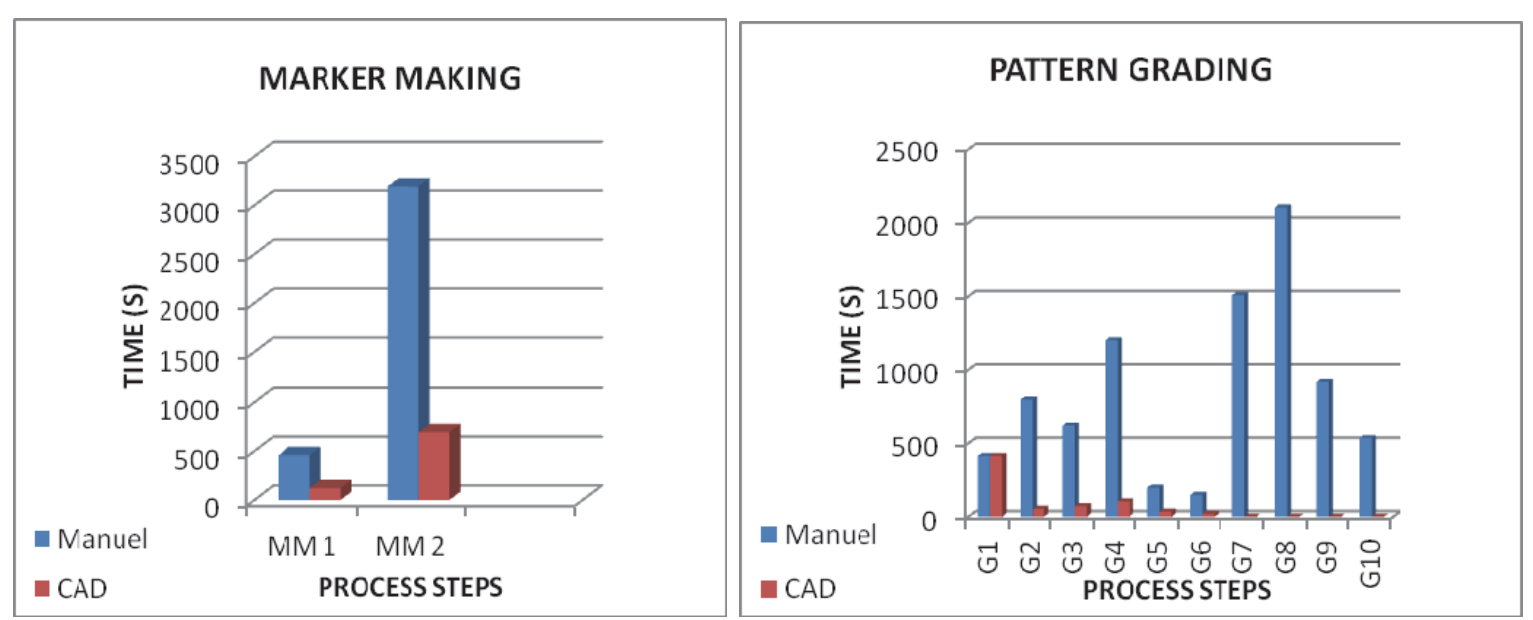

Figure 6. Comparison of Manual and CAD Systems in Terms of Process Time for Grading and Marker Making

The comparison of CAD systems and the manual method in grading shows that process times were shorter for CAD systems than the manual method (Figure 6). Upon individual analysis of the stages, it is observed that for example, the same process of front body grading in the manual method is 12 times greater than the time required for CAD systems. Besides, while the time required to complete the stages involved in preparing cardboard patterns for every size constitute $50 \%$ of total grading process time, performing the same task on CAD systems takes no time at all.

The comparison of CAD systems and the manual method in marker-making shows that process times were shorter for CAD systems than the manual method (Figure 6). Analysis shows that, for example, the time required to perform the $2^{\text {nd }}$ stage-positioning the patterns onto the marker-manually takes approximately 4.6 times longer than completing the same task on CAD systems. In other words, it can be said that the same process of curve drawing was completed on CAD systems in just $22 \%$ of the time spent doing it manually.

The main purpose of using CAD systems for the markermaking process is, in addition to saving time, to lower costs by minimizing fabric waste. In this manner also, it has been observed that length of markers prepared on CAD systems are less than those prepared manually (Table 4).

The comparison of CAD systems and the manual method in upper-body garment in terms of obtained process times for basic pattern making, modelling, grading and marker making reveals that for all 4 processes, process times were shorter for CAD systems than the manual method (Figure 7). The evaluation of total time has demonstrated that the time required to complete the whole process manually takes 5.8 times longer than completing the same task on CAD systems. In other words, the whole process can be completed on CAD systems in just $17 \%$ of the time spent doing it manually.

Upon analysis of process stages, it has been found that the biggest difference in terms of time was in the grading process. It is observed that the whole process time for grading in the manual method is 12 times greater than the time required on CAD systems. The second biggest difference in process times was in the modelling stage. It was also found that the time required to perform the whole process manually takes 8 times longer than completing the same task on CAD systems.

In the marker-making process also, the time required to perform the whole process manually takes 4.5 times longer than completing the same task on CAD systems. The comparison also reveals that the time required to perform the basic pattern making process manually takes 1.3 times longer than completing the same task on CAD systems.

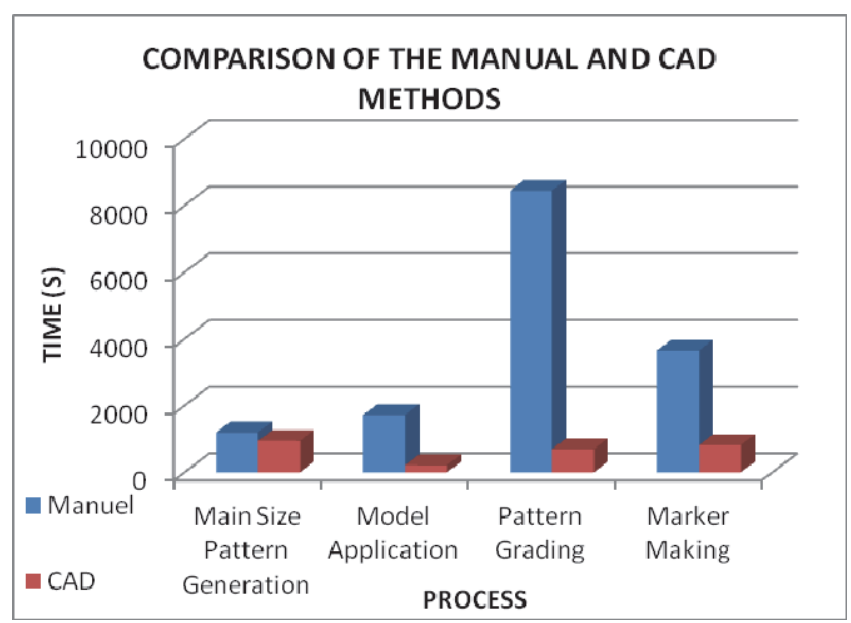

Figure 7. Comparison of Process Stages in terms of Process Time for the Manual Method and CAD Systems

Table 5 shows data acquired through the analysis of findings belonging to sub procedures that form the processes via Mann Whitney test, and Table 6 shows the data acquired by analyzing basic process times via the Mann Whitney test. Study of the data belonging to sub procedures shown in Table 5 indicates that for especially the sub procedures involved in modelling, grading and clothspreading, the time required to perform the process manually is longer than the one required for completing the same task on CAD systems, and that the difference is statistically significant.

According to the data in Table 6, it can be stated that total times for pattern making, modelling, grading and marker making, and therefore, for total process, was shorter on $C A D$ systems and that the difference was statistically significant. 
Table 4. Comparison of Manual and CAD Systems in terms of Marker Lengths

\begin{tabular}{|l|l|l|l|c|c|c|}
\hline & \multicolumn{1}{|c|}{ Manuel 1 } & Manuel 2 & Manuel 3 & CAD 1 & CAD 2 & CAD3 \\
\hline Marker Length $(\mathrm{cm})$ & 405 & 423 & 403 & 381 & 370 & 366 \\
\hline
\end{tabular}

Table 5. Findings obtained from the evaluation of the data obtained in the research with the Mann Whitney $U$ test

\begin{tabular}{|c|c|c|c|c|c|c|c|}
\hline $\begin{array}{l}\text { Steps } \\
\text { No }\end{array}$ & Methods & Min & Max & Median & $\begin{array}{c}\mathrm{P} \\
(\mathrm{P}<0,05)\end{array}$ & $\begin{array}{l}\text { Significiant of } \\
\text { Difference }\end{array}$ & Favourity Method \\
\hline \multirow{2}{*}{ PM 1} & Manuel & 173 & 201 & 185 & \multirow{2}{*}{0,27523} & \multirow{2}{*}{ No Significiant } & \multirow{2}{*}{ between the two methods } \\
\hline & CAD & 102 & 192 & 155 & & & \\
\hline \multirow{2}{*}{ PM 2} & Manuel & 73 & 93 & 91 & \multirow{2}{*}{0,82726} & \multirow{2}{*}{ No Significiant } & \multirow{2}{*}{ between the two methods } \\
\hline & CAD & 63 & 98 & 77 & & & \\
\hline \multirow{2}{*}{ PM 3} & Manuel & 58 & 65 & 61 & \multirow{2}{*}{0,04953} & \multirow{2}{*}{ Significiant } & \multirow{2}{*}{ Manuel } \\
\hline & CAD & 67 & 136 & 75 & & & \\
\hline \multirow{2}{*}{ PM 4} & Manuel & 171 & 213 & 176 & \multirow{2}{*}{0,04953} & \multirow{2}{*}{ Significiant } & \multirow{2}{*}{ CAD } \\
\hline & CAD & 90 & 137 & 110 & & & \\
\hline \multirow{2}{*}{ PM 5} & Manuel & 110 & 129 & 115 & \multirow{2}{*}{0,37583} & \multirow{2}{*}{ No Significiant } & hetween the two methods \\
\hline & CAD & 79 & 117 & 110 & & & Detween tne two metnoas \\
\hline PMG & Manuel & 86 & 116 & 115 & 004053 & Sianificiant & 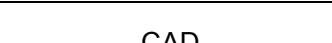 \\
\hline rivio & CAD & 45 & 70 & 62 & 0,04900 & Signimicialit & CAD \\
\hline PM 7 & Manuel & 54 & 65 & 62 & 051269 & $\mathrm{No}$ Sianificiant & hetween the two methods \\
\hline & CAD & 0 & 87 & 78 & 0,51209 & No Signimiciant & Detween tne two metnoas \\
\hline PM 8 & Manuel & 64 & 71 & 65 & 0.51269 & No Sianificiant & between the two methods \\
\hline & CAD & 34 & 98 & 45 & & & \\
\hline PM 9 & Manuel & 126 & 131 & 126 & 0.50656 & No Sianificiant & between the two methods \\
\hline PIVIS & CAD & 77 & 163 & 95 & 0,50050 & No signiliclant & Detween tne two metnoas \\
\hline PM 10 & Manuel & 50 & 59 & 55 & 0.04953 & Sianificiant & CAD \\
\hline FIVI IO & CAD & 12 & 48 & 34 & 0,04950 & Sigmincraint & CAD \\
\hline PM 11 & Manuel & 27 & 38 & 30 & 004053 & Sianificiant & CAR \\
\hline FIVI II & CAD & 2 & 26 & 10 & 0,04953 & signimciant & CAD \\
\hline PM 12 & Manuel & 52 & 87 & 56 & 0.51269 & No Sianificiant & between the two methods \\
\hline & CAD & 42 & 60 & 55 & 0,01209 & TNO Signimiciantit & Detweent are two medrous \\
\hline PM 13 & Manuel & 31 & 61 & 40 & 012118 & No Sianificiant & hetween the two methods \\
\hline rivit IJ & CAD & 19 & 38 & 19 & $0,1<110$ & TVu Signimicianti & 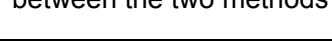 \\
\hline$M 1$ & Manuel & 291 & 408 & 371 & 004953 & Sianificiant & CAD \\
\hline 政1 & CAD & 5 & 31 & 15 & 0,04903 & Signimiciant & CAD \\
\hline M2 & Manuel & 468 & 551 & 520 & 0,04953 & Sianificiant & CAD \\
\hline & CAD & 29 & 111 & 108 & & & \\
\hline$M 3$ & Manuel & 410 & 564 & 531 & 0.03690 & Significiant & CAD \\
\hline 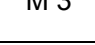 & CAD & 0 & 0 & 0 & & & \\
\hline M 4 & Manuel & 148 & 290 & 207 & 0.04953 & Significiant & CAD \\
\hline & CAD & 0 & 27 & 9 & & & \\
\hline M 5 & Manuel & 81 & 155 & 145 & 0.27523 & No Significiant & between the two methods \\
\hline 列 & CAD & 76 & 152 & 78 & 0,21520 & TNO Signimiciant & Detween the awo mentroas \\
\hline G 1 & Manuel & 413 & 413 & 413 & 1 & No Sianificiant & between the two methods \\
\hline ا & CAD & 413 & 413 & 413 & 1 & INO Signimiciant & Detween tne two metnoas \\
\hline G 2 & Manuel & 775 & 824 & 795 & 0.04953 & Sianificiant & CAD \\
\hline & CAD & 18 & 121 & 22 & & & \\
\hline G 3 & Manuel & 488 & 696 & 675 & 0.04953 & Sianificiant & CAD \\
\hline & CAD & 43 & 91 & 82 & & & \\
\hline$G 4$ & Manuel & 942 & 1349 & 1311 & 004953 & Sianificiant & CAD \\
\hline G4 & CAD & 42 & 181 & 91 & 0,04953 & Significlant & CAD \\
\hline$G 5$ & Manuel & 181 & 224 & 190 & 0,04953 & Sianificiant & CAD \\
\hline & CAD & 19 & 49 & 33 & & & \\
\hline$G 6$ & Manuel & 131 & 158 & 155 & 0.04953 & Sianificiant & CAD \\
\hline 0 & CAD & 4 & 41 & 14 & & & \\
\hline MM 1 & Manuel & 432 & 492 & 448 & 0.04953 & Sianificiant & CAD \\
\hline & CAD & 88 & 178 & 101 & & & \\
\hline MM 2 & Manuel & 2293 & 4175 & 3109 & 0,04953 & Significiant & CAD \\
\hline & CAD & 546 & 807 & 730 & & & \\
\hline
\end{tabular}


Table 6. Findings obtained as a result of assessment of values by means of Mann Whitney Test

\begin{tabular}{|c|c|c|c|c|c|c|c|}
\hline $\begin{array}{c}\text { Basic Steps } \\
\text { No }\end{array}$ & Methods & Min & Max & Median & $P(P<0,05)$ & $\begin{array}{l}\text { Significiant of } \\
\text { Difference }\end{array}$ & $\begin{array}{l}\text { Favourity } \\
\text { Method }\end{array}$ \\
\hline \multirow{2}{*}{ BS1 } & Manuel & 1163 & 1216 & 1202 & \multirow{2}{*}{0,0495} & \multirow{2}{*}{ Significiant } & \multirow{2}{*}{ CAD } \\
\hline & CAD & 747 & 1137 & 943 & & & \\
\hline \multirow{2}{*}{ BS2 } & Manuel & 1521 & 1904 & 1713,3 & \multirow{2}{*}{0,0495} & \multirow{2}{*}{ Significiant } & \multirow{2}{*}{ CAD } \\
\hline & CAD & 131 & 268 & 213,7 & & & \\
\hline \multirow{2}{*}{ BS3 } & Manuel & 7743 & 9171 & 8442,3 & \multirow{2}{*}{0,0495} & \multirow{2}{*}{ Significiant } & \multirow{2}{*}{ CAD } \\
\hline & CAD & 539 & 887 & 696,3 & & & \\
\hline \multirow{2}{*}{ BS4 } & Manuel & 2741 & 4607 & 3649,7 & \multirow{2}{*}{0,0463} & \multirow{2}{*}{ Significiant } & \multirow{2}{*}{ CAD } \\
\hline & CAD & 634 & 908 & 816,7 & & & \\
\hline \multirow{2}{*}{ TOTAL } & Manuel & 14032 & 16898 & 14067 & \multirow{2}{*}{0,0495} & \multirow{2}{*}{ Significiant } & \multirow{2}{*}{ CAD } \\
\hline & CAD & 2079 & 2880 & 2748 & & & \\
\hline
\end{tabular}

\section{DISCUSSION}

In the study conducted, using manual and CAD systems for upper-body garment were compared in terms of total process time calculated for garment basic pattern making, modelling, grading and marker making processes. The data collected throughout the study has revealed that in every stage of process that are crucial in pre-production preparation stage, the process times for CAD systems are shorter when compared to those of manual drawing. The evaluation of total process time shows that the time required for the completion of all the processes manually is about 5.8 times greater than that required for CAD systems. In other words, the same process was completed using CAD systems in just $17 \%$ of the time spent for all the processes manually. Moreover, when the data obtained in the study was evaluated by Mann Whitney $U$ test, it was observed that total times for pattern making, modelling, grading and marker making, and therefore, for total process, was shorter on CAD systems and the difference was statistically significant.

Upon analysis of process stages, it was found that the biggest difference in terms of time was in the grading stage. The second biggest difference in process times was in the modelling stage, which was followed by marker making and finally, basic pattern making.

In the grading and modelling processes, the source of the cause for the time loss in manual drawing has been determined as the stages of copying pattern parts onto cardboard and seam allowance. In the manual method, after the modelling and grading stages, pattern parts for each size have to be transferred onto cardboard. During transfer, especially pattern curves might vary from size to size, and the sizes obtained in grading may not match the main size. On the other hand, after the grading chart has been loaded onto CAD systems, the grading is performed automatically, which leads to no differences between the main size and the graded sizes. Transferring the pattern onto cardboard in the manual method has a negative effect not only because it takes a longer time but also in terms of labor and quality. Usually, at apparel companies, an assistant is assigned to the modelist for the task of preparing the cardboard pattern. During the transfer of the pattern onto cardboard and the cutting, accurate transfer of especially of curved lines fails and the accuracy of the pattern is left up to the less experienced assistant's talent. Separation of pattern pieces from the main pattern is performed in a very short amount of time on CAD systems; for example, seam allowance can be added simultaneously to all the patterns.

Analysis of data on upper-body clothing in the study by Purin (2013) also reveals that the least amount of time saved on CAD systems was in basic pattern making process.

Comparison reveals that the time required to complete the basic garment pattern making process manually is about 1.3 times longer than that required to perform it on CAD systems. However, analysis of individual steps that make up the process stage reveals that there is not any significant difference between the methods for the seven steps including drawing extension lines, marking measurements, drawing back and shoulder darts.

This situation is considered to stem from the fact that CAD operators are not efficient in using the relevant CAD tools for basic pattern making. In the apparel sector, pattern designers usually prefer to prepare the patterns manually, and then, to transfer them onto the computer via digitizer. This way, the time spent on transferring the pattern to the system by digitizer is also added to the time spent on manual drawing. Moreover, during transfer to the system, especially the curves of the pattern may sometimes not be accurately converted. This may also affect the accuracy of body fit. However, in the study conducted, the basic pattern was made using the tools provided on the CAD systems and this was observed to save time. Nevertheless, it is believed that efficient use of CAD systems is likely to save much more time.

The study demonstrates that the time required to manually perform the marker-making process is about 4.5 times longer than that required for the CAD systems. It was also found that this difference is statistically significant $(p=0.046)$. The study shows that the effort made to properly place the grainline and the process of marking dart places during the manual process causes the process to take a longer time. Also during manual marker making process, it is essential to pay attention not to use too many or too few patterns, and also to accurately position the patterns' left and right sides 
while fabric spreading stage. The main purpose of using CAD systems for the marker-making process is to minimize the amount of wasted fabric in order to lower the cost. As put forth by the study by Naveed et al. (2017), cloth cost constitutes about $50-60 \%$ of total raw-material costs in clothing production (9). Therefore, marker making is important for both ensuring production quality and lowering cost per unit. In this study also, it was observed that cloth spreading length on CAD systems is $9 \%$ shorter than the one in the manual method.

It is a fact that CAD systems basically help save time, labor and resources. The study conducted also supports that CAD systems provide saving on these three factors. As emphasized in the study, CAD systems also provide an advantage to the firm on sustainable quality production. Production is performed with basic patterns on which the last touch on the basic pattern curves prepared on CAD systems is made by the person in charge of the pattern design. This way, the patterns preserve their originality throughout the basic pattern-making, modelling and grading processes, and also, possible mistakes by pattern assistants while transferring patterns onto cardboard are avoided. It is also believed that on CAD systems, where sufficient attention has been paid to placing the grainline, higher quality markers will be made

\section{CONCLUSION}

There can be a significant improvement in productivity \& quality, leading time to drop with the use of computers in Apparel Sector. It can also be helpful for waste reduction in pattern designing, grading \& alteration time. It gives greater flexibility in pattern designing, grading and marking

With the fact of globalization in today's world, each day brings about more competition to apparel sector, just like every other. To ensure competitive superiority, it is necessary for production firms to rapidly make and launch products of a large variety at reasonable costs and desired levels of quality. As the findings of the study maintain, CAD systems shorten preparation processes, lowers error rate, sustainable quality production, and provides efficiency in material use, labor and production value.

Looking at the whole, it is seen that the basic pattern making process is the last item in terms of time saved, and that the time differences between the two methods occur in the stages of drawing extension lines, marking measurements, and making back and shoulder darts. This situation is considered to stem from the fact that CAD operators are not efficient in using the relevant CAD tools for basic pattern making.

For these reasons, it is necessary for Apparel Company to follow new technologies regarding CAD systems and provide training for their employees on these developing technologies. As a conclusion, it was suggested that, the software companies need to simplify and ease the software regarding basic pattern preparation. Using CAD for pattern making in apparel industry is always a very open \& creative process. It is expected that, the outcomes of this study will contribute to the improvement of $2 D$ and $3 D$ CAD systems.

\section{REFERENCES}

1. Puri A., 2013, Efficacy of Pattern Making Software in Product Development, International Journal of Advanced Quality Management, Volume 1, Issue 1, pp. 21-39

2. Dabolina, I; Vilumsone, A., 2012, The Role of the Latest Clothing CAD/CAM System Applications in the Educational Process, Material Science, Textile and Clothing Technology Vol. 7, pp:63.

3. Şen, A., Öndoğan, Z., 2004. Hazır giyim koleksiyonu hazırlığında CAD sistemlerinin kullanımı, IV. Ulusal Üretim Araştırmaları Sempozyumu, Konya

4. Tabraz, M., 2017, Importance Of Fashion Cad (Computer Aided Design) Study For Garment Industry In Bangladesh, Internatıonal Journal Of Scientific\& Technology Research V:6, I:10.

5. Kayaalp, İ., D., Öndoğan, Z., 2004, Hazır Giyim Endüstrisinde Giysi Kalıbı ve Kesim Planı Hazırlama İşlemlerinde CAD Sistemlerinin Kullanımı, IV. Ulusal Üretim Araştırmaları Sempozyumu, Konya

6. Dumishllari E., Guxho, G.,2015, Impact of Marker on Cut Plan in Garment Production, International Journal of Innovative Research in Science, Engineering and Technology (An ISO 3297: 2007 Certified Organization) Vol. 4, Issue 8.

7. Rahman, M.F., Rashid, M. R., Haque E.and Hasan, Z., 2017, Effect of Garment Size Ratio and Marker Width Variation on Marker Efficiency for both Manual and Computerized Marker; European Journal of Advances in Engineering and Technology, 4(10): 765-772

8. W Wong and SYSLeung, A Hybrid Planning for Improving Fabric Utilization, Textile Research Journal, 2009, 79(18), 1680-1695.

9. Naveed T., Hussain A. and Zhong Y., 2017; Reducing fabric wastage through image projected virtual marker (IPVM); sagepub.co.uk/journalsPermissions.nav.

10. Stjepanovic, Z., Computer-aided processes in garment production Features of CAD/CAM hardware, International Journal of Clothing Science and Technology, Vol. 7 No. 2/3, 1995, pp. 81-88.

11. Singh S., Singh R., 2017, Development of a CAD Tool for Pattern Making of Garments; International Journal of Innovative Computer Science \& Engineering Volume 4 Issue 2; March-April-2017; Page No. 11-15

12. Öndoğan Z. And Erdoğan Ç. M., 2006; The Comparison of the Manual and CAD Systems for Pattern Making, Grading and Marker Making Processes, Fibres \& Textiles in Eastern Europe January / March 2006, Vol. 14, No. 1 (55)

13. Özkan, M., 2006, Türkiye'de Hazır Giyim Sektöründe Kullanılan Bilgisayar Destekli Kalıp Hazırlama Sistemlerinden Assyst, Konsancad ve Lectra Sistemlerinin Karşılaştırılması, Selçuk Üniversitesi Sosyal Bilimler Enstitüsü Yüksek Lisans Tezi, Konya, s.s:93

14. Şen Kılıç, A.; Yücel, Ö., 2011, Konfeksiyon Üretiminde Konvansiyonel ve Bilgisayar Destekli Kalıp Hazırlama Yöntemlerinin Birim Maliyetler Açısından Karşılaştırılması, 2011, Konfeksiyon Teknik, P.P:62-66

15. Göksel, N., Utkun E., Öndoğan Z., 2012, Giysi Tasarımında Bilgisayar Destekli Kalıp Hazırlama Yönteminin Kullanımı, Tekstil ve Konfeksiyon, 4/2012, p.p:375-382

16. Kayar, M., Dal, V., Mıstık, S.I, 2015, Investigating The Effect of The Marker Assortment Size Distribution and Fabric Width on The Fabric Use Efficiency; Industria Textila, 2015, vol. 66, nr. 3, p.p:142

17. Haque,M. N., 2016, Impact of Different Sorts of Marker Efficiency in Fabric Consumption, International Journal of Textile Science 2016, 5(5): 96-109

18. Kansoy O., Erdoğan M, 2006, Giysi Model Özelliklerinin Parça Sayısı, Parça Çevresi ve Dikim Süresi İle İlişkileri, Tekstil ve Konfeksiyon, 2006(1), s.s:320324 